\title{
FITOTERAPIA
}

Fitoterapia 73 (2002) 674-684

www.elsevier.com/locate/fitote

\section{Antiproliferative effects of Ceratonia siliqua L. on mouse hepatocellular carcinoma cell line}

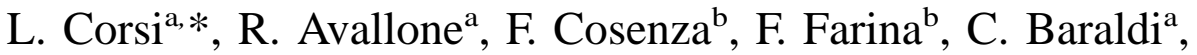 \\ M. Baraldi ${ }^{\mathrm{a}}$ \\ a'Department of Pharmaceutical Sciences, Via Campi, 183, Modena and Reggio Emilia University, \\ 41100 Modena, Italy \\ ${ }^{\mathrm{b}}$ Department of Internal Medicine, Via del Pozzo, 71 Modena and Reggio Emilia University, \\ 41100 Modena, Italy
}

Received 4 July 2002; accepted in revised form 18 September 2002

\begin{abstract}
Extracts from pods and leaves of carob (Ceratonia siliqua L.) were tested for their ability to inhibit cell proliferation of mouse hepatocellular carcinoma cell line (T1). The two extracts showed a marked alteration of $\mathrm{T} 1$ cell proliferation in a dose-related fashion reaching the maximal effect at $1 \mathrm{mg} / \mathrm{ml}$. Moreover, we demonstrated that leaf and pod extracts were able to induce apoptosis in T1 cell lines after 24-h treatment mediating a direct activation of the caspase 3 pathway. HPLC analysis revealed the presence of gallic acid, ( - ) epigallocatechin3 -gallate and $(-)$ epicatechin-3-gallate in pod and leaf extracts, compounds well known to exert antiproliferative effects. Their concentration reached $6.28 \mathrm{mg} / \mathrm{g}$ in carob leaves and $1.36 \mathrm{mg} / \mathrm{g}$ in carob pods extract. The discovery that carob pod and leaf extracts contained antiproliferative agents could be of practical importance in the development of functional foods and/or chemopreventive drugs.
\end{abstract}

(C) 2002 Elsevier Science B.V. All rights reserved.

Keywords: Ceratonia siliqua; Cell proliferation; Apoptosis; Caspase 3; ( - ) Epigallocatechin-3-gallate; (-) Epicatechin-3-gallate

\section{Introduction}

Ceratonia siliqua $\mathrm{L}$. is a typical plant of the Mediterranean area, which is mainly used in the food industry as source of gum extracted from the seeds. Carob meal

*Corresponding author. Tel.: +39-059-2055138; fax: +39-059-2055131.

E-mail address: corsi.lorenzo@unimo.it (L. Corsi).

0367-326X/02/\$ - see front matter (C) 2002 Elsevier Science B.V. All rights reserved. PII: S 0367-326X(02)00227-7 
contains among total polyphenols a high level of proanthocyanidins in comparison to hydrolysable ones represented by ellagitannins and gallotannins [1].

Interest has focused on flavonoids potential benefits to human health, as they are ubiquitously present in foods of plant origin and some epidemiological studies evidenced that the consumption of foods rich in these compounds could reduce the risk for certain types of cancer and heart diseases mortality [2-5]. In this context, it has been shown that oral consumption of polyphenols offers protection against all stages of carcinogenesis [5,6]. Several mechanisms of anticancer activity of catechins have been postulated, such as an inhibition of urokinase [7], inhibition of angiogenesis [8] and inhibition of cell growth and proliferation processes [9], but none seem universal for all cancers.

Recent studies have demonstrated that also theaflavins, procyanidins and other naturally occurring low molecular phenolic acids, such as gallic, chlorogenic and caffeic acid, have strong antioxidant and cancer chemopreventive properties [1014].

The aim of the present study was to investigate the ability of aqueous extract of pod and leaf of carob to inhibit cell proliferation of mouse hepatocellular carcinoma cell line (T1).

\section{Experimental}

\subsection{Materials}

Samples of pod and leaf of C. siliqua were collected during August-September 2001 in the eastern parts of Sicily (Italy) where they naturally grow and identified by Prof. P. Zanoli, Prof. of Pharmacognosy, Department of Pharmaceutical Sciences, college of Pharmacy, Modena and Reggio Emilia University (Modena, Italy). Voucher specimen was deposited in the same University. Samples were stored at room temperature and analysed within 2 months of collection. The plant material (pod or leaf) was crushed in a mechanical mill and the resulting powder was extracted as described below.

Standards of $(+)$-catechin (C), ( - )-epicatechin (EC), ( - )-epigallocatechin-3gallate (EGCG), (-)-epicatechin-3-gallate (ECG), (-)-epigallocatechin (EGC), gallic acid (GAc), theophilline $(\mathrm{T})$, caffeine $(\mathrm{Ca})$, chlorogenic acid $(\mathrm{ClAc})$, caffeic acid (CAc) and cathecol (Ct), were purchased from Sigma (Milan, Italy). HPLCgrade methanol and acetonitrile and phosphoric acid of analytical grade were purchased from Carlo Erba Reagenti (Milan, Italy). For the preparation of all samples and solutions distilled water deionized with Milli-Q Water Purification System (Millipore, Bedford, Massachusetts, USA) was used.

\subsection{Extracts preparation}

The extracts were prepared infusing $1 \mathrm{~g}$ of carob pods or leaves powder with 100 $\mathrm{ml}$ of boiling water for $15 \mathrm{~min}$. The infusions were then centrifuged at $20000 \times \mathrm{g}$ 
for $10 \mathrm{~min}$ and the supernatants were collected and lyophilised. The lyophilised samples were then used for the assay on cell proliferation and apoptosis.

For HPLC analysis the supernatant was collected, filtered through 0.45 and 0.22 mm Cellulose Acetate filter devices (Sigma) and then diluted properly in water.

\subsection{Cells and treatments}

The T1 cell line, originally cloned from the solid hepatocellular carcinoma from transgenic mice showing an over expression of $c-m y c$ and TGF $\alpha$ genes, was a kind gift of Dr Snorri Thorgeirsson (Chief, Laboratory of Experimental Carcinogenesis Division of Basic Sciences, National Cancer Institute, NIH, Bethesda, MA).

The cell lines were cultured on polystyrene culture dishes (Dasit, Milano, Italy) and grown in DMEM without L-glutamine plus HAM's F 12 medium (1:1), containing $1 \mathrm{mg} / \mathrm{ml}$ galactose, $18 \mathrm{mM}$ HEPES, $5 \mathrm{mM}$ Na pyruvate, $30 \mathrm{mg} / \mathrm{ml}$ proline, $10 \%$ ITS $100 \times, 2 \mathrm{mM}$ glutamine, $0.1 \%$ gentamicin (all purchased from Sigma-Aldrich, Milano, Italy) referred as T1 medium (T1M) and supplemented with $10 \%$ FBS. For the assay a solution of lyophilised samples in T1M medium ranging from 1 to $0.1 \mathrm{mg} / \mathrm{ml}$ was used. The number of cells was assessed by optical microscope using a magnification $40 \times$ (Nikon, Japan).

\subsection{BrdU cell proliferation assays}

T1 cells were plated on 96-well plates at concentration of $\sim 10000$ cells/well in T1M and supplemented with either 10 or $0.1 \%$ FBS. The cells were then incubated with different concentrations from 1 to $0.1 \mathrm{mg} / \mathrm{ml}$ of pod or leaf extracts for $24 \mathrm{~h}$; $4 \mathrm{~h}$ prior to the end of incubation, 5-bromo-2'-deoxyuridine (BrdU) was added to each well $(10 \mu \mathrm{M})$. Differences in cell proliferation were analysed by measuring the amount of BrdU incorporation determined by a Multiskan MCC 340 system (Labsystem Oy, Helsinki, Finland). Incorporation was measured at $450 \mathrm{~nm}$ (reference at $690 \mathrm{~nm})$.

\subsection{Detection of apoptosis}

\subsubsection{TUNEL-modified assay}

T1 cells line were seeded on cover sleeps in 35-mm dishes (Dasit) in the appropriate culture medium. Apoptosis was assessed by the terminal-deoxynucleotidyltransferase (TnT)-mediated dUTP-biotine Nick-End Labelling modified assay (TUNEL), using a DeadEnd Colorimetric Apoptosis Detection System provided by Promega (Milano, Italy).

Briefly, the cells treated with $0.2 \mathrm{mg} / \mathrm{ml}$ of leaf extracts or $0.4 \mathrm{mg} / \mathrm{ml}$ of pod extracts for $24 \mathrm{~h}$ were rinsed in PBS and fixed in $4 \%$ paraformaldehyde solution, washed with PBS and incubated with biotinylated nuclotides for $60 \mathrm{~min}$ at $37^{\circ} \mathrm{C}$, washed with PBS and incubated for $5 \mathrm{~min}$ at room temperature in $0.3 \%$ hydrogen peroxide (Sigma). Cells were then rinsed in PBS and detection of DNA fragmen- 
Table 1

Gradient elution system

\begin{tabular}{|c|c|c|c|c|}
\hline $\begin{array}{l}\text { Time } \\
(\min )\end{array}$ & $\begin{array}{l}\% \mathrm{~A} \\
\mathrm{H}_{2} \mathrm{O}\end{array}$ & $\begin{array}{l}\% \mathrm{~B} \\
0.5 \% \text { Phosphoric } \\
\text { acid }\end{array}$ & $\begin{array}{l}\% \mathrm{C} \\
\text { Acetonitrile }\end{array}$ & $\begin{array}{l}\% \text { D } \\
\text { Methanol }\end{array}$ \\
\hline 0 & 68 & 22 & 4 & 6 \\
\hline 18 & 58 & 22 & 8 & 12 \\
\hline 23 & 54 & 22 & 12 & 12 \\
\hline 40 & 36 & 22 & 30 & 12 \\
\hline
\end{tabular}

tation was carried out by incubating the cells with DAB solution for $10 \mathrm{~min}$ at room temperature.

The staining was assessed by optical microscope using a magnification $40 \times$ (Nikon, Japan).

\subsubsection{Protease assay}

Caspase-3-related protease activity in cell lysates was determined using a commercially available kit (Promega). Briefly, T1 cells were treated with $0.2 \mathrm{mg} / \mathrm{ml}$ of leaf extracts or $0.4 \mathrm{mg} / \mathrm{ml}$ of pod extracts alone or in association with the pancaspase inhibitor Z-VAD-FMK $(50 \mu \mathrm{M})$ for $24 \mathrm{~h}$. Cell lysate proteins (nuclei free), were mixed with assay buffer (containing $10 \mathrm{mM}$ DTT) and with the colorimetric substrate DEVD-pNA $(20 \mu \mathrm{mol})$ followed by incubation at $37{ }^{\circ} \mathrm{C}$ for $4 \mathrm{~h}$. Absorbance was then read at $405 \mathrm{~nm}$ using a Multiskan MCC 340 system.

\subsection{HPLC analysis}

The main stock solutions of all standards were prepared by dissolving weighted quantities of the analytes in the initial mobile phase used for the chromatographic separation $\mathrm{H}_{2} \mathrm{O}$ /phosphoric acid 0.5\%/acetonitrile/methanol (68:22:4:6). Catechins, gallic acid, caffeine and theophilline were prepared at the concentration of $10 \mathrm{mg} /$ $\mathrm{ml}$; chlorogenic acid at the concentration of $25 \mathrm{mg} / \mathrm{ml}$; caffeic acid at the concentration of $30 \mathrm{mg} / \mathrm{ml}$; cathecol at the concentration of $80 \mathrm{mg} / \mathrm{ml}$ and the tea extract at the concentration of $75 \mathrm{mg} / \mathrm{ml}$. The standard mixtures for calibration were prepared diluting these stock solutions in the same mobile phase with concentrations ranging from 0.25 to $500 \mu \mathrm{g} / \mathrm{ml}$. Stock solutions and standards mixtures were stored in darkness at $-20{ }^{\circ} \mathrm{C}$.

The HPLC system consisted of a LaChrom L-7100 quaternary pump, a L-7612 Vacuum Solvent Degasser for in-line degassing of the mobile phase, a rheodyne manual injector with a $50 \mu$ l loop and a LaChrom L-7455 Diode Array Detector. Data analysis was performed using a D-7000 computer interface and a D-7000 HPLC System Manager software (Merck-Hitachi, Darmstadt, Germany).

The chromatographic separation was performed on an analytical Microsorb-MV ${ }^{\mathrm{TM}}$ $\mathrm{RP}^{-\mathrm{C}_{18}} 100 \AA$ column $(250 \times 4.6 \mathrm{~mm})$, placed in a water bath set at $40{ }^{\circ} \mathrm{C}$. The solvents used for gradient elution were (a) $\mathrm{H}_{2} \mathrm{O}$, (b) phosphoric acid $0.5 \%$, (c) 
acetonitrile and (d) methanol; the flow rate was set at $1 \mathrm{ml} / \mathrm{min}$; and the gradient elution profile is presented in Table 1 . After every injection, the column was reequilibrated with initial conditions for $15 \mathrm{~min}$. UV-Vis absorbance spectra $(\lambda=$ $198-708 \mathrm{~nm}$ ) were collected continuously during the course of each chromatogram and used for the peak purity determination. Peaks in the samples were identified by comparing their retention times and UV-Vis spectra with those of the reference standards, after subtraction of the corresponding base spectrum. Peak areas obtained at $205 \mathrm{~nm}$ were used for the construction of calibration curves.

\subsection{Statistical analysis}

All experiments were repeated at least three times to ensure the reproducibility. All assays and quantitative measurements were performed in quadruplicate. Comparison of multiple means was performed with one-way ANOVA with the Bonferroni's test and Dunnett's post hoc test (Graph Pad Inc.) Ps for unpaired $t$-test and one-way ANOVA are provided in the text.

\section{Results}

\subsection{Modulation of $T 1$ cell proliferation}

Incubation of $\mathrm{T} 1$ cell line for $24 \mathrm{~h}$ with pod and leaf extracts of carob significantly inhibited the proliferation of the carcinoma cell line. The two extracts showed a marked reduction of $\mathrm{T} 1$ cell proliferation in a dose-related fashion reaching the maximal effect at $1 \mathrm{mg} / \mathrm{ml}$ (Fig. 1). In particular, the treatment with $0.2,0.4$ and $0.8 \mathrm{mg} / \mathrm{ml}$ of extracts, produced a significant inhibition $(P<0.001)$ of incorporation of BrdU, whereas at $0.1 \mathrm{mg} / \mathrm{ml}$, both extracts did not show any significant change compared to the non-treated cells.

Interestingly, the $\mathrm{IC}_{50}$ of leaf extracts was lower than that of pods extracts, ranging from 0.2 to $0.4 \mathrm{mg} / \mathrm{ml}$, respectively, suggesting the presence, in the leaf extract, of a considerably higher amount of compounds able to inhibit cell proliferation.

\subsection{Induction of apoptosis}

Pod and leaf extracts were able to induce apoptosis in T1 cell lines as indicated by the darker staining of nuclei of treated cells. The DNA fragmentation was evident after 24-h treatment (Fig. 2b,c). The exposure to the vehicle did not cause nuclear alterations as confirmed by the absence of any staining (Fig. 2a). The effect on apoptosis elicited by leaf extracts used at $0.2 \mathrm{mg} / \mathrm{ml}$ was greater than that obtained with pod extracts used at $0.4 \mathrm{mg} / \mathrm{ml}$.

Cell lysates treated with pod and leaf extracts exhibited a significant increase in peptide cleavage activity compared to the non-treated cells $(P<0.05)$. The observed cleavage of DEVD was mostly due to the activation of the caspase pathway, since 


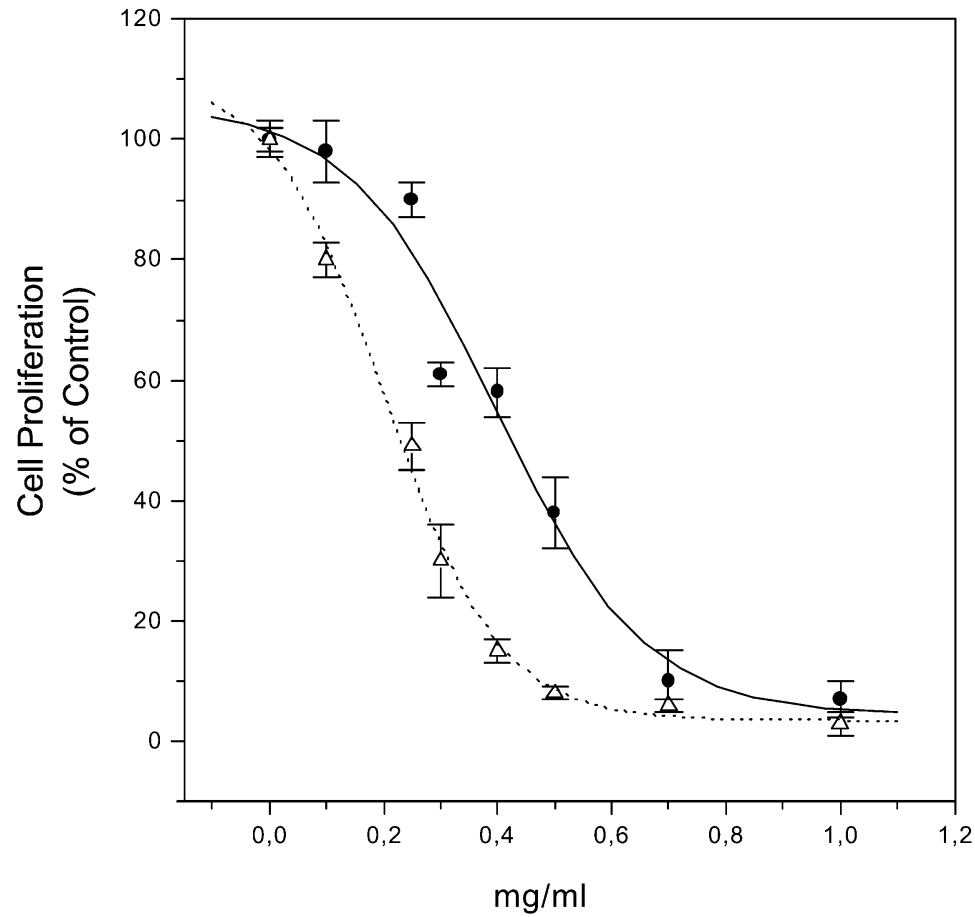

Fig. 1. Effect of aqueous extract of pods and leaves of carob on cell proliferation of mouse hepatocellular carcinoma cell line (T1). Inhibition of $\mathrm{T} 1$ cells proliferation elicited by pod extract (straight line) and leaf extract (dots line) are expressed as \% of control \pm S.E. One way ANOVA (Dunnett test) indicates that $\mathrm{T} 1$ cell proliferation was significantly inhibited by treatment with leaf and pod extracts at all the concentrations tested $(P<0.001)$.

pre-treating the T1 cells with the pan-caspase inhibitor Z-VAD-FMK induced a complete block of the DEVD cleavage (Fig. 3).

\subsection{Analysis of polyphenols}

The chromatogram of an injection of a standard mixture at optimum conditions is shown in Fig. 4 and the characteristics of the standard mixtures are reported in Table 2. All compounds exhibited good linearity over the range tested, with correlation coefficients of 0.992-0.999. The UV-Vis spectra obtained for each standard peak, after subtraction of the UV-Vis base spectrum, were computer normalised, superimposed and utilised for sample identification.

The quantitative results are reported in Table 3. Every peak was analysed using DAD and the HSM software: peak purity check confirmed that there were no coeluting compounds affecting the separation, meanwhile identification was carried out comparing retention times and UV-Vis spectra $\left(r^{2}\right.$ always $\left.>0.97\right)$ with that of standards. GAc, EGCG and ECG were found both in pod and leaf extracts while C 

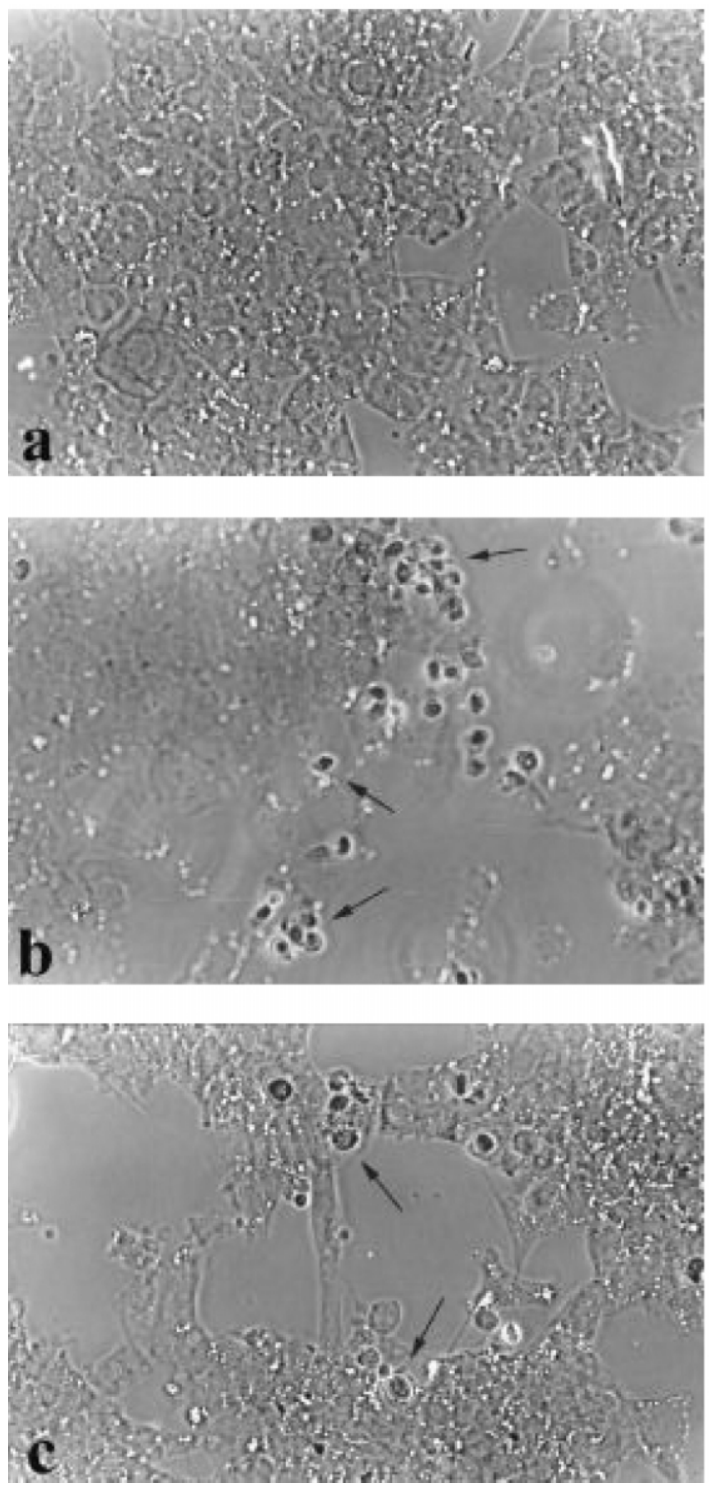

Fig. 2. Effect of aqueous extract of pods and leaves of carob on apoptosis in mouse mouse hepatocellular carcinoma cell line (T1). Treatments with leaf extracts $[0.2 \mathrm{mg} / \mathrm{ml},(b)]$ or pod extracts $[0.4 \mathrm{mg} / \mathrm{ml}$, (c)] causes DNA fragmentation in many cells as shown by the dark brown nuclear staining (arrows), indicating an increase of apoptotic processes. On the contrary, non-treated cells (a) showed no dark staining. Magnification $40 \times$. 


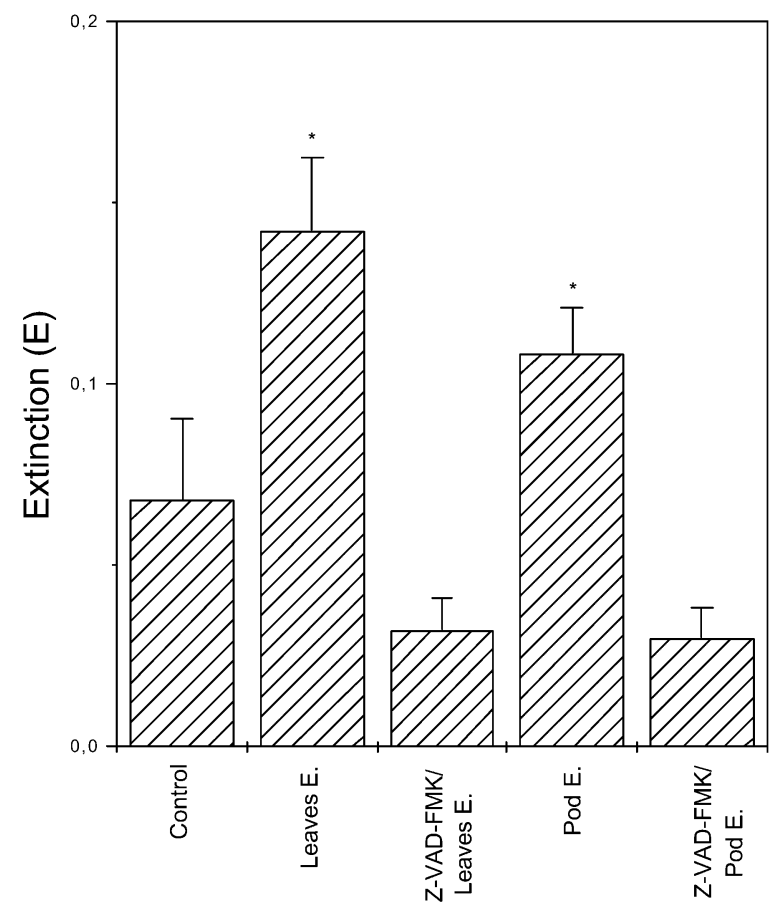

Fig. 3. Effect of aqueous extract of pods and leaves of carob on caspase-3 activity in mouse hepatocellular carcinoma cell line (T1). One way ANOVA (Bonferroni) indicates that induction of caspase-3 activity was significantly inhibited by treatment with leaf and pod extracts at $24 \mathrm{~h}(*=P<0.05)$.

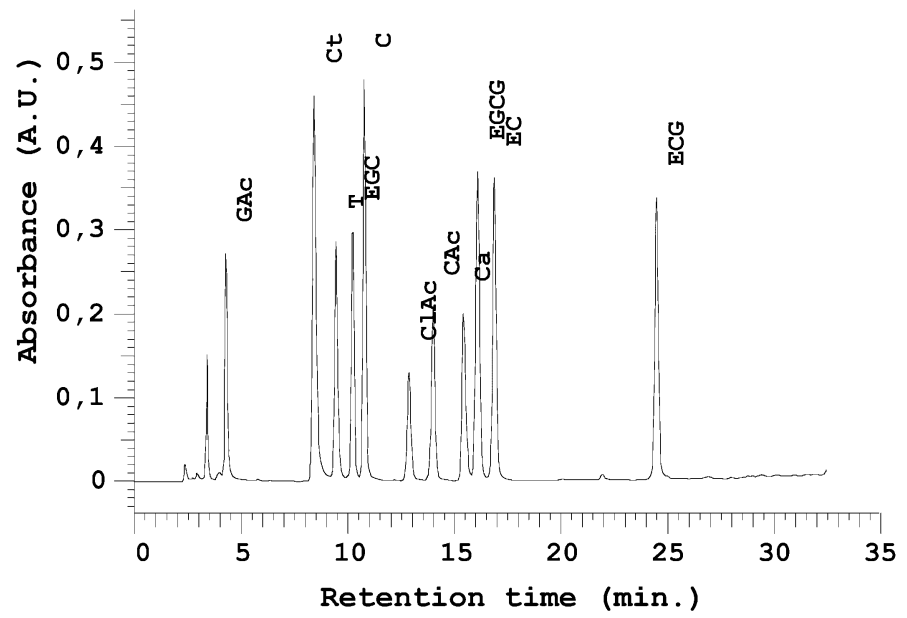

Fig. 4. Chromatogram at $\lambda=205 \mathrm{~nm}$ of a standard mixture $(25 \mu \mathrm{g} / \mathrm{ml} \mathrm{ClAc} ; 15 \mu \mathrm{g} / \mathrm{ml} \mathrm{CAc} ; 5 \mu \mathrm{g} / \mathrm{ml}$ all other analytes). 
Table 2

Standards characteristics, linearity and day-to-day variation

\begin{tabular}{|c|c|c|c|c|c|c|c|}
\hline & \multirow[t]{2}{*}{$\mathrm{RT} \pm$ S.D..$^{\mathrm{a}}$} & \multirow[t]{2}{*}{$\begin{array}{l}\text { Concentration range } \\
(\mu \mathrm{g} / \mathrm{ml})\end{array}$} & \multicolumn{2}{|c|}{$\begin{array}{l}\text { Linear regression }{ }^{\mathrm{b}} y= \\
a X+b\end{array}$} & \multirow[t]{2}{*}{$\begin{array}{l}\text { Correlation } \\
\text { coefficient }\end{array}$} & \multicolumn{2}{|c|}{$\begin{array}{l}\text { Coefficient of vari- } \\
\text { ation }(\%)^{c}\end{array}$} \\
\hline & & & $a$ & $b$ & & Intra-day & Inter-day \\
\hline $\mathrm{G} \mathrm{Ac}$ & $4.2 \pm 0.03$ & $0.3-80$ & 168783.6 & 299258.36 & 0.994 & 3.89 & 4.01 \\
\hline $\mathrm{Ct}$ & $8.4 \pm 0.11$ & $1-350$ & 81635.2 & 1576306 & 0.994 & 3.63 & 3.79 \\
\hline $\mathrm{T}$ & $9.4 \pm 0.06$ & $0.3-80$ & 229789.8 & 394896.7 & 0.993 & 3.80 & 4.03 \\
\hline EGC & $10.3 \pm 0.07$ & $0.3-80$ & 248701.5 & 666964.0 & 0.994 & 4.23 & 4.42 \\
\hline $\mathrm{C}$ & $10.8 \pm 0.07$ & $0.3-80$ & 285714.7 & 1313438 & 0.992 & 3.68 & 3.68 \\
\hline $\mathrm{Cl} \mathrm{Ac}$ & $12.8 \pm 0.1$ & $0.8-250$ & 51577.30 & 21809.91 & 0.999 & 3.65 & 4.19 \\
\hline $\mathrm{C} \mathrm{Ac}$ & $13.9 \pm 0.11$ & $0.7-200$ & 93713.66 & 58917.54 & 0.999 & 3.30 & 4.19 \\
\hline $\mathrm{Ca}$ & $15.4 \pm 0.11$ & $0.3-80$ & 229155.4 & 131290.0 & 0.999 & 4.95 & 5.19 \\
\hline EGCG & $16.1 \pm 0.14$ & $0.3-80$ & 320218.6 & 1358269 & 0.998 & 3.10 & 4.42 \\
\hline EC & $16.9 \pm 0.15$ & $0.3-80$ & 308116.2 & 904935.5 & 0.994 & 3.67 & 3.93 \\
\hline ECG & $24.4 \pm 0.13$ & $0.3-80$ & 313256.1 & 725123.9 & 0.997 & 4.39 & 4.62 \\
\hline
\end{tabular}

${ }^{a}$ Values are average of 18 determinations \pm standard deviation (S.D.).

${ }^{\mathrm{b}}$ Results derived from linear regression analysis of standard peak areas (UV/s) at $205 \mathrm{~nm}$ vs. known concentrations $(\mu \mathrm{g} / \mathrm{ml}) ; y=$ peak area, $x=$ concentration; all determinations are the mean of at least three replicates for six different concentrations.

${ }^{\mathrm{c}}$ Values are results of three runs a day for 3 consecutive days.

was present, although only in small amounts, in carob pod extracts. EC, one of the major polyphenols found in green and black tea, was absent in both extracts. The polyphenols detected in our experimental conditions reached $6.28 \mathrm{mg} / \mathrm{g}$ in carob leaves and $1.36 \mathrm{mg} / \mathrm{g}$ in carob pod extracts.

Table 3

Total amount of polyphenol present in carob leaves and pods extracts

\begin{tabular}{|c|c|c|c|c|c|c|}
\hline & \multicolumn{3}{|c|}{ Carob leaves $\mathrm{mg} / \mathrm{g} \pm$ S.D. ${ }^{*}$} & \multicolumn{3}{|c|}{ Carob pod mg/g \pm S.D. ${ }^{*}$} \\
\hline & I infusion & II infusion & Total & I infusion & II infusion & Total \\
\hline $\mathrm{G} \mathrm{Ac}$ & $3.34 \pm 0.03$ & $0.96 \pm 0.02$ & 4.30 & $0.87 \pm 0.00$ & $0.33 \pm 0.00$ & 1.20 \\
\hline $\mathrm{Ct}$ & - & - & - & - & - & - \\
\hline $\mathrm{T}$ & - & - & - & - & - & - \\
\hline EGC & - & - & - & $0.05 \pm 0.00$ & $0.01 \pm 0.00$ & 0.06 \\
\hline $\mathrm{C}$ & - & - & - & $0.01 \pm 0.00$ & - & 0.01 \\
\hline $\mathrm{Cl} \mathrm{Ac}$ & - & - & - & - & - & - \\
\hline $\mathrm{Ca} \mathrm{Ac}$ & - & - & - & - & - & - \\
\hline $\mathrm{Ca}$ & - & - & - & - & - & - \\
\hline EGCG & $1.23 \pm 0.41$ & $0.28 \pm 0.03$ & 1.51 & $0.01 \pm 0.00$ & - & 0.01 \\
\hline $\mathrm{EC}$ & - & - & - & - & - & - \\
\hline ECG & $0.47 \pm 0.09$ & - & 0.47 & $0.06 \pm 0.00$ & $0.02 \pm 0.00$ & 0.08 \\
\hline Total & 5.04 & 1.24 & 6.28 & 1.00 & 0.36 & 1.36 \\
\hline
\end{tabular}

${ }^{*}=$ Mean and S.D. of three determinations. 


\section{Discussion}

In these last years relevant attention has been focused on the capability of dietary constituents such as the epicatechins, the polyphenolic compounds present in large amounts, i.e. in green tea, to act as chemopreventives and anticarcinogens [15]. The idea to use fruits and leaves of carob, a typical Mediterranean plant, as a source of polyphenols, was raised after the evidence that carob pods contained a high amount of antioxidant compounds such as gallotannins [1]. Up to now, carob pods are mainly devoted to animal feeding because of their excessive astringency due to the high presence of the tannins. We started, then, to characterise qualitatively and quantitatively the polyphenols present in carob pods in order to figure out the possibility to extract such compounds and to use it as nutraceutical preparation, and in addition, to obtain a high quality pod meal with less astringency property. In this ongoing project we found that substances present in the pods aqueous extracts, exerted a good anti-proliferative effect on T1 cell line.

This result prompted us to study if the extracts of other parts of the plant were able to induce the same effect. In particular we used the carob leaves, thought to be a better source of these compounds and in particular of polyphenols. Our results indeed showed that carob leaves extract produced an inhibition of T1 cell proliferation significantly higher than that produced by carob pods extract at all the concentrations tested. This effect seems to be related to the induction of apoptosis, since the leaf and pod extracts showed, even if with different potency, a significant increase of caspase- 3 activity compared to that found in the control cells. Given the extraordinary ability of green tea leaf extracts, which are rich in catechins, to inhibit cell proliferation, we could surmise that the effects elicited by the two extracts, could be primarily related to the presence of gallotannins and gallic acid. As pointed out in the results, we found a higher amount of different flavonoids, such as EGCG and ECG and also of the GAc in the leaf extracts compared to the pod extracts. However, since we tested the activity of total extracts, we cannot exclude that other compounds could contribute to the inhibition of tumoral cell proliferation.

Although further studies are necessary to evaluate the molecular basis which underwent the effect of these compounds, our findings could represent an improvement in the biological and pharmacological characterisation of the compounds present in $C$. siliqua.

Moreover, given the extraordinary ability of leaf and pod extracts to inhibit tumour cell proliferation our finding could be useful for the future strategies against the cell mitogenic activity and, therefore, cancer progression.

\section{References}

[1] Avallone R, Plessi M, Baraldi M, Monzani AJ. Food Comp Anal 1997;10:166-172.

[2] Kunze E, Chang-Claude J, Frentzel-Beyme R. Cancer 1992;69:1776-1790.

[3] Kinlen LJ, Willows AN, Goldblatt P, Yudkin J. Br J Cancer 1988;58:397-401. 
[4] Ken J. Prev Med 1992;21:385-391.

[5] Katiyar SK, Mukhtar H. Int J Onol 1996;8:221-238.

[6] Katiyar SK, Agarwal R, Wang ZY, Bhatia AK, Mukhtar H. Nutr Cancer 1992;18:73-83.

[7] Jankun J, Selman SH, Swiercz R. Nature 1997;387:561.

[8] Cao Y, Cao R. Nature 1999;398:381.

[9] Lepley BM, Li B, Birt BF, Pelling JC. Carcinogenesis 1996;17:2367-2375.

[10] Dong Z, Ma W, Huang C, Yang CS. Cancer Res 1997;57:4414-4419.

[11] Chung JY, Huang C, Meng X, Dong Z, Yang CS. Cancer Res 1999;59:4610-4617.

[12] Lin J-K, Chen P-C, Ho C-T, Lin-Shiau S-Y. J Agric Food Chem 2000;48:2736-2743.

[13] Kumazawa S, Taniguchi M, Suzuki Y, Shimura M, Kwon MS, Nakayama TJ. Agric Food Chem 2002;50:373-377.

[14] Kasai H, Fukafa S, Yamaizumi Z, Sugie S, Mori H. Food Chem Toxicol 2000;38:467-471.

[15] Hirota F, Masami S, Sachiko O, Eisaburo S, Kenji S, Kazue I, et al. P.S.E.B.M. 1999;220:225228. 